\title{
Don Lindberg: A Seven-Decade Friendship
}

\author{
Carl M. PELLMAN M.D. ${ }^{1}$ \\ Urology, Elmhurst, NY. U.S.A.
}

Keywords. Donald A.B. Lindberg, M.D., Amherst College, Oscar E. Schotte

I met Don Lindberg in the 1950s through Frederic Edelman, a neurosurgeon currently of Encino, California, whose family and mine are close. When Fred discovered his two good friends would attend Amherst, he got us together, and a lifelong friendship began.

At Amherst, Don and I shared an interest in biology, in which we both majored. In our junior year, we developed a special, mutual interest in experimental embryology. At that time, I began to appreciate Don's quiet and creative genius as we studied for exams together long into the night and worked in the laboratory of Amherst Professor Oscar Emile Shotte on the regeneration of limbs in amphibia. Don concentrated on developing frogs, and I focused on newts.

In springtime, armed with nets, Don and I (and our class) joined Prof. Shotte to search local caves and ponds for experimental subjects. Following each spring hunt, we celebrated with a keg of beer and local Polish spreadable sausage with rye bread.

We spent idyllic afternoons drinking wine in Prof. Shotte's office, talking about experimental biology, politics, and women, subjects to which we were all attentive. It was so meaningful and fun to work with Shotte that we continued during the summers following college graduation and between our first and second years of medical school at the College of Physicians and Surgeons (P and S), Columbia University.

After completing medical school, Don did not take a customary year of internship in medicine or surgery. Instead, Don persuaded P and S's Department of Pathology to design an internship just for him. While it was highly unusual to create an internship tailored to one individual, the decision attests to Don's extraordinary abilities.

Indeed, Don was remarkably attached to Columbia University for many reasons. After all, it was there (in the Pediatric Outpatient Clinic) where he met his wife-to-be, Mary. The rumor was when the time was right; he would formally request her hand in marriage. The latter was a good decision.

While I lost contact with Don for some years after his wedding, it was a pleasure to renew our friendship when he and Mary returned to the eastern U.S. in the 1980s. During his tenure as director of the National Library of Medicine, Don revitalized the library and made a magnificent contribution to medicine and science.

Finally, it is an honor to write about Don and a friendship that spanned seven decades.

1 Corresponding author: carlmpellmanmd@aol.com 